
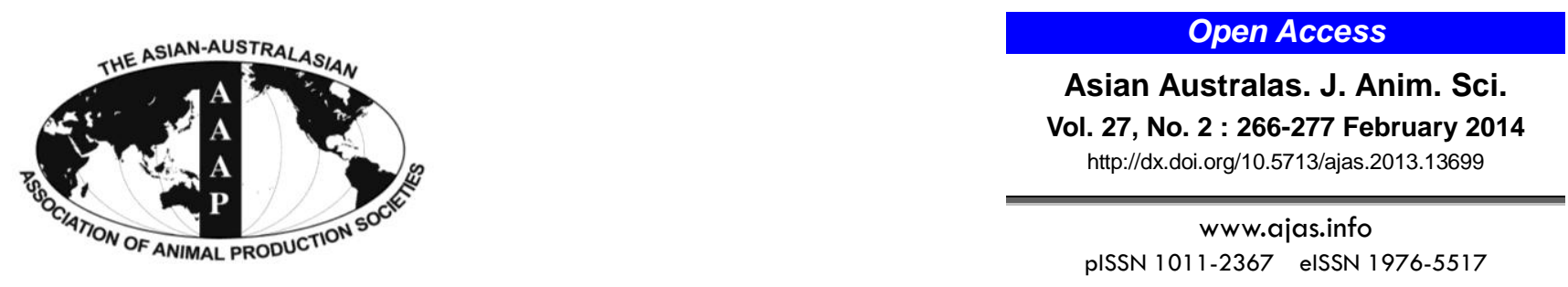

\title{
Siberian Sturgeon Oocyte Extract Induces Epigenetic Modifications of Porcine Somatic Cells and Improves Developmental Competence of SCNT Embryos
}

\author{
So-Young Kim, Tae-Suk Kim, Sang-Hoon Park, Mi-Ran Lee, Hye-Ju Eun, Sang-Ki Baek, \\ Yeoung-Gyu Ko ${ }^{1}$, Sung-Woo Kim ${ }^{1}$, Hwan-Hoo Seong ${ }^{1}$, Keith H.S. Campbell ${ }^{2}$, and Joon-Hee Lee ${ }^{3, *}$ \\ Department of Animal Bioscience, College of Agriculture and Life Sciences, \\ Gyeongsang National University, Jinju, 660-701, Korea
}

\begin{abstract}
Somatic cell nuclear transfer (SCNT) has generally demonstrated that a differentiated cell can convert into a undifferentiated or pluripotent state. In the SCNT experiment, nuclear reprogramming is induced by exposure of introduced donor nuclei to the recipient cytoplasm of matured oocytes. However, because the efficiency of SCNT still remains low, a combination of SCNT technique with the ex-ovo method may improve the normal development of SCNT embryos. Here we hypothesized that treatment of somatic cells with extracts prepared from the germinal vesicle (GV) stage Siberian sturgeon oocytes prior to their use as nuclear donor for SCNT would improve in vitro development. A reversible permeability protocol with $4 \mu \mathrm{g} / \mathrm{mL}$ of digitonin for $2 \mathrm{~min}$ at $4^{\circ} \mathrm{C}$ in order to deliver Siberian sturgeon oocyte extract (SOE) to porcine fetal fibroblasts (PFFs) was carried out. As results, the intensity of H3K9ac staining in PFFs following treatment of SOE for $7 \mathrm{~h}$ at $18^{\circ} \mathrm{C}$ was significantly increased but the intensity of $\mathrm{H} 3 \mathrm{~K} 9 \mathrm{me} 3$ staining in PFFs was significantly decreased as compared with the control $(\mathrm{p}<0.05)$. Additionally, the level of histone acetylation in SCNT embryos at the zygote stage was significantly increased when reconstructed using SOE-treated cells $(\mathrm{p}<0.05)$, similar to that of IVF embryos at the zygote stage. The number of apoptotic cells was significantly decreased and pluripotency markers (Nanog, Oct4 and Sox2) were highly expressed in the blastocyst stage of SCNT embryos reconstructed using SOE-treated cells as nuclear donor ( $\mathrm{p}<0.05)$. And there was observed a better development to the blastocyst stage in the SOE-treated group $(\mathrm{p}<0.05)$. Our results suggested that pre-treatment of cells with SOE could improve epigenetic reprogramming and the quality of porcine SCNT embryos. (Key Words: Epigenetic Modifications, Somatic Cell Nuclear Transfer, Siberian Sturgeon Oocyte Extract)
\end{abstract}

\section{INTRODUCTION}

During development, embryonic cells undergo a series

\footnotetext{
* Corresponding Author: Joon-Hee Lee. Tel: +82-55-772-1886, Fax: +82-55-772-1889, E-mail: sbxjhl@gnu.ac.kr

${ }^{1}$ Animal Genetic Resources Station, National Institute of Animal Science, Rural Development Administration, Namwon, 590-832, Republic of Korea.

${ }^{2}$ Animal Development and Biotechnology Group, Department of Animal Science, School of Biosciences, The University of Nottingham, Sutton Bonington, Loughborough, Leicestershire LE12 5RD, United Kingdom.

${ }^{3}$ Institute of Agriculture and Life Science, College of Agriculture and Life Sciences, Gyeongsang National University, Jinju, 660701, Korea.
}

Submitted Nov. 7, 2013; Accepted Nov. 25, 2013; Revised Nov. 29, 2013 of processes such as modifications of nuclear and chromatin structure and give rise to specific cell types of an organism. Acquisition and maintenance of the differentiation state can be stably inherited through cell division and proliferation whereas reversion of a differentiated cell to an undifferentiated or pluripotency cell state is strictly inhibited in normal development (Jouneau and Renard, 2003). Such direct conversion would be a promising approach for animal biotechnology and regenerative medicine.

The ability to reprogram differentiated somatic cells was first demonstrated in mammals by the generation of animals after somatic cell nuclear transfer (SCNT) (Wilmut et al., 1997; Wakayama et al., 1998), and followed by the generation of pluripotent stem cells from terminally 
differentiated fibroblast cells by retroviral transduction of defined pluripotent transcription factors (Takahashi et al., 2006). Recently, alternative approaches to reprogramming of differentiated somatic cells into an embryonic pluripotent state have been developed as cellular fusion (Tada et al., 1997; Blasu et al., 1999), the use of cell or oocyte extract (Alberio et al., 2005; Taranger et al., 2005; Bian et al., 2009) and culture-induced reprogramming (Konrad and Rudolf, 2006).

Even though the SCNT-derived offspring have been successfully produced in all mammalian species, the efficiency of development to term is still low. It was continually reported that most of cloned offspring produced by SCNT technique show rudimentary figures or abnormalities (Tang et al., 2009; Rathbone et al., 2010). One of the reasons causing these problems is incomplete or incorrect reprogramming of somatic nucleus following introduced into the recipient cytoplasm, giving rise to epigenetic defects (Morgan et al., 2005). With the purpose of solving these problems several researches have been developed favourable reprogramming of donor nuclei by means of some extrinsic factors before exposure to the recipient environment.

The ex-ovo system for epigenetic reprogramming of a terminately differentiated cell depends on the transient uptake of regulatory components from a nuclear and cytoplasmic mixtures derived from cell extract (Håkelien et al., 2002; Landsverk et al., 2002). In the pioneering studies with amphibians and mammals, it was demonstrated that epigenetic reprogramming of differentiated mammalian cells were successfully induced to a pluripotent state by exposing amphibian oocyte extracts (Hochedilinger et al., 2002; Alberio et al., 2005; Bian et al., 2009). When ovine SCNT embryos reconstructed by using donor cells pretreated with Xenopus laevis germinal vesicle (GV) oocyte extracts were transferred into surrogate, the pregnancy and survival rate were greatly improved (Rathbone et al., 2010). Miyamoto et al. (2007) has been reported that porcine metaphase (MII) oocyte extract replaces transcription factors from donor nuclei with the oocyte extract and eventually increases the histone deacetylation in the somatic nuclei. It has been reported that the transcriptional reprogramming of human and bovine nuclei increased after treatment of cells in extracts from Xenopus laevis oocytes or egg (Hansis et al., 2004; Alberio et al., 2005). Furthermore, these cells showed up-regulation in the expression of pluripotency markers (Oct4, Sox2, and Nanog) and formed outgrowth colonies which similar with morphology of embryonic stem cells (ESCs) (Miyamoto et al., 2008).

As mentioned above, the use of totipotent or pluripotent cell extract for pre-treatment of donor cells prior to SCNT has been expected to improve epigenetic reprogramming of cloned embryos and eventually enhance the frequency of development to term. Due to the limitation in accessibility of mammalian oocytes, non-mammalian eggs the large number and volume would be a tempting alternative. In generally, Xenopus laevis oocytes at the germinal vesicle (GV) stage are extremely larger than mammalian oocytes and accessible with relative ease. Like Xenopus laevis oocytes, a Siberian sturgeon spawns approximately hundreds of thousand oocytes at a time and the size of a sturgeon oocyte is excessively lager than that of a mammalian oocyte (approximately $4.0 \mathrm{~mm}$ in diameter) (Campman and Van Eenennaam, 2007). Therefore, Siberian sturgeon oocyte can be a good source to study the molecular mechanisms underlying epigenetic reprogramming. So far, no one has ever studied using ichthyic oocyte extract for epigenetic reprogramming of mammalian species, which might be worth studying. Thus, we used the oocyte extract of Siberian sturgeon to alter the epigenetic modifications such as DNA methylation and histone acetylation in the nuclei of porcine somatic cells. Finally, the effects of pretreatment of donor cells with the oocyte extract prior to SCNT on the subsequent development of porcine SCNT embryo were determined.

\section{MATERIALS AND METHODS}

All chemicals were purchased from Sigma-Aldrich Company (St. Louis, MO, USA) unless otherwise stated.

\section{Collection and culture of porcine oocyte}

Porcine ovaries were collected at a local slaughterhouse and transported to the laboratory in PBS at $39^{\circ} \mathrm{C}$. Cumulusoocyte complexes (COCs) were aspirated from 2 to $5 \mathrm{~mm}$ of antral follicles in diameter using 18-gauge needle. Goodquality oocytes surrounded by at least three layers of cumulus cells were selected in TL-HEPES buffer. Oocyte were washed three times in Bicarbonate-buffered TCM 199 (Gibco) supplemented with 10\% PVA, $3.05 \mathrm{mM}$ D-glucose, $0.91 \mathrm{mM}$ Na-pyruvate, $0.57 \mathrm{mM}$ Cysteine, $75 \mu \mathrm{g} / \mathrm{mL}$ Penicillin, $50 \mu \mathrm{g} / \mathrm{mL}$ Streptomycin, $10 \mathrm{ng} / \mathrm{mL}$ EGF, 1 $\mu \mathrm{g} / \mathrm{mL}$ FSH, $5 \mu \mathrm{g} / \mathrm{mL}$ LH. Porcine COCs were initially washed twice in $13 \mathrm{mM}$ Brilliant Cresyl Blue (BCB) medium supplemented with $4 \mathrm{mg} / \mathrm{mL}$ BSA and incubated for $90 \mathrm{~min}$ at $39^{\circ} \mathrm{C}$ in humidified atmosphere of $5 \% \mathrm{CO}_{2}$. Following exposure to $\mathrm{BCB}$, only $\mathrm{COCs}$ stained blue color were selected for oocyte maturation under a stereomicroscope. To synchronize meiotic maturation, COCs were pre-incubated in maturation medium supplemented with $5 \mu \mathrm{g} / \mathrm{mL}$ of CHXM for $16 \mathrm{~h}$ (Ye et al., 2002). Following treatment with CHXM, the COCs then washed thoroughly washed in maturation medium and further cultured without CHXM. All culture drops containing oocytes were covered with a thin layer of mineral oil pre-equilibrated with medium and incubated in 
$5 \% \mathrm{CO}_{2}$ in humidified air at $39^{\circ} \mathrm{C}$.

\section{In vitro fertilization}

The diluted porcine semen was transported to the laboratory. After washing once by centrifugation at $750 \mathrm{~g}$ for 3 min, spermatozoa were resuspended at a concentration of $1 \times 10^{8}$ cells. Cumulus cells were removed from COCs by pipetting for several times in TL-hepes with $0.1 \%(\mathrm{w} / \mathrm{v})$ hyaluronidase. Groups of 15 oocytes were then incubated in a concentration of $5 \times 10^{5} \mathrm{sperm} / \mathrm{ml}$ of PZM5 medium supplemented with $20 \mathrm{~mL} / \mathrm{L}$ BME amino acids, $10 \mathrm{~mL} / \mathrm{L}$ MEM-nonessential amino acids, $3 \mathrm{mg} / \mathrm{mL}$ BSA (fatty acid free) and cultured at $39^{\circ} \mathrm{C}$ in $5 \% \mathrm{O}_{2}, 5 \% \mathrm{CO}_{2}$. On day 2 , cleaved embryos were transferred into fresh PZM5 medium until the blastocyst stage.

\section{Preparation of porcine fetal fibroblasts}

Porcine fetal fibroblasts (PFFs) were isolated from 30 day old fetus and cultured for a 4 to 5 passages in DMEM containing $1.25 \%$ MEM-nonessential amino acids, $1.25 \%$ $\beta$-mercaptoethanol, $1 \%$ penicillin/streptomycin supplemented with $10 \% \mathrm{FBS}$ at $39^{\circ} \mathrm{C}$ in $5 \% \mathrm{CO}_{2}$. Primary cultures were then stored in liquid nitrogen until used. Cells were thawed and then cultured until $80 \%$ confluent. PFFs for SCNT were synchronized at the G0 stage by 3-5 ays in the DMEM supplemented with $0.1 \%$ FBS.

\section{Permeabilization and cell viability of PFFs treated with digitonin}

Permeabiliszation and cell viability of PFFs treated with digitonin were assessed by $0.8 \mathrm{mM}$ trypan blue solution for 1 day. The cells were divided into two groups; trypan blue+ (colored nucleus; permeable membrane) and trypan blue(colorless nucleus; non permeable membrane).

\section{Preparation of Siberian sturgeon oocyte extract}

In the spring, Siberian sturgeon oocytes were collected from mature females and then removed jelly coat in collagenase solution $\left(8 \mathrm{mg} / \mathrm{mL}\right.$ type II collagenase in $\mathrm{Ca}^{2+}$ free Ringers solution) for $30 \mathrm{~min}$. After dejellying, the oocytes were washed three times in Ringer's buffer and then necrotic oocytes were removed (Campman and Van Eenennaam, 2007). Only good quality oocytes were collected in tubes and rinsed three times in ice cold extraction buffer (20 mM Hepes [pH 7.5], $100 \mathrm{mM} \mathrm{KCl,} 5$ $\mathrm{mM} \mathrm{MgCl}_{2}$ ) added protease inhibitors (2 $\mathrm{mM} \beta$ Mercaptoethanol, $3 \mu \mathrm{g} / \mathrm{mL}$ Leupeptin, $1 \mu \mathrm{g} / \mathrm{mL}$ Aprotinin, 1 $\mu \mathrm{g} / \mathrm{mL}$ Pepstatin A). The oocytes were moved into centrifuge tubes (Beckman, USA) and centrifuged at 10,000 $\mathrm{g}$ for $15 \mathrm{~min}$ at $4^{\circ} \mathrm{C}$ using an ultracentrifuge (Optima XL$100 \mathrm{~K}$, Beckman). These steps were performed for several times. The middle layer was taken and recentrifuged at
$100,000 \mathrm{~g}$ for $30 \mathrm{~min}$ at $4^{\circ} \mathrm{C}$. These steps were also performed for several times. The collected cytoplasm was supplemented with 5\% glycerol and stored at liquid nitrogen until used.

\section{Incubation of PFFs with Siberian sturgeon oocyte extract}

PFFs were trypsinized and then permeabilized with 4 $\mu \mathrm{g} / \mathrm{mL}$ of digitonin in $\mathrm{PB}$ buffer $(170 \mathrm{mM}$ potassium gluconate, $5 \mathrm{mM} \mathrm{KCl}, 2 \mathrm{mM} \mathrm{MgCl} 2,1 \mathrm{mM} \mathrm{KH} \mathrm{PO}_{4}, 1 \mathrm{mM}$ EGTA, $20 \mathrm{mM}$ HEPES) supplemented with $2 \mathrm{mM}$ DTT, 3 $\mu \mathrm{g} / \mathrm{mL}$ Leupeptin, $1 \mu \mathrm{g} / \mathrm{mL}$ Aprotinin and $1 \mu \mathrm{g} / \mathrm{mL}$ Pepstatin A ( $\mathrm{pH} \mathrm{7.25)} \mathrm{for} 2 \mathrm{~min}$ at $4^{\circ} \mathrm{C}$. Following treatment with digitonin $10 \mathrm{~mL}$ of $\mathrm{PB}$ buffer was added and then centrifuged at $700 \times \mathrm{g}$ for $10 \mathrm{~min}$ at $4^{\circ} \mathrm{C}$. The permeabilized cells by digitonin were exposed to SOE for $7 \mathrm{~h}$ at $15^{\circ} \mathrm{C}$ to $18^{\circ} \mathrm{C}$ with agitation every hour. After incubation with SOE, cells were centrifuged in the permeabilization buffer.

\section{Immunocytochemistry for DNA methylation and histone acetylation}

After treatment of SOE, PFFs were placed onto a cover slip by centrifuge (Centurion Scientific Ltd, UK), fixed $4 \%$ paraformaldehyde solution for $15 \mathrm{~min}$ and then washed three times with PBS-T $(0.1 \%$ Tween 20 , and $7.7 \mathrm{mM}$ sodium azide in PBS) for $5 \mathrm{~min}$. These cells were blocked with blocking solution (5\% BSA in PBS-T) for $1 \mathrm{~h}$ at room temperature and then incubated in the primary antibody: Histone H3 Lys-9 methylation (H3K9me3, 1:250, Abcam, UK) or Histone H3 Lys-9 acetylation (H3K9ac, 1:250, Milipore, USA) for overnight at $4^{\circ} \mathrm{C}$. After incubation with the primary antibody these cells were washed three times with PBS-T for $5 \mathrm{~min}$. The secondary antibody was followed: Alexafluor 488 goat anti-rabbit $\operatorname{IgG}(1: 150$, Invitrogen, USA) for $1 \mathrm{~h}$ at room temperature. Nucleus of cells were stained with propidium lodide $(0.5 \mu \mathrm{L} / \mathrm{mL}$ in PBS) for $10 \mathrm{~min}$ at room temperature and mounted with VECTASHIELD (Vector Laboratories, Inc, USA). Images were captured a fluorescence microscope (LEICA DM 2500, Switzerland). On the other hand, porcine embryos were fixed $4 \%$ paraformaldehyde solution for $1 \mathrm{~h}$ and then washed three times with PBS-T. After being washed embryos were permeabilized with $0.5 \%$ Triton $\mathrm{X}-100$ in PBS for $30 \mathrm{~min}$ at $4{ }^{\circ} \mathrm{C}$ and then washed three times. These embryos were blocked in blocking solution for overnight at $4^{\circ} \mathrm{C}$. They were then incubated in the primary antibody: $\mathrm{H} 3 \mathrm{~K} 9 \mathrm{ac}\left(1: 300\right.$, Milipore) for $1 \mathrm{~h}$ at $37^{\circ} \mathrm{C}$ and washed several times in PBS-T. Embryos were followed by incubated with the secondary antibody: Alexafluor 488 goat anti-rabbit $\operatorname{IgG}(1: 150$, Invitrogen) for $1 \mathrm{~h}$ at room temperature without the light. After being washing several times, embryos were stained with propidium lodide (50 
$\mathrm{pg} / \mathrm{mL}$ ) for $10 \mathrm{~min}$ at room temperature and mounted with VECTASHIELD.

\section{Flow cytometry}

SOE treated cells were fixed with $4 \%$ paraformaldehyde solution for $15 \mathrm{~min}$ at $4^{\circ} \mathrm{C}$. These fixed cells were rinsed in DPBS without $\mathrm{Mg}^{2+}$ and $\mathrm{Ca}^{2+}, 0.1 \%$ PVA and blocked with blocking solution (DPBS without $\mathrm{Mg}^{2+}$ and $\mathrm{Ca}^{2+}, 0.1 \%$ PVA, $1 \% \mathrm{BSA}$ ) for $30 \mathrm{~min}$ at $4^{\circ} \mathrm{C}$. They were added by the antibody of H3K9ac (1:100, Milipore) or H3K9me3 (1:100, Abcam, UK) for $45 \mathrm{~min}$ at $4{ }^{\circ} \mathrm{C}$ and incubated in the secondary antibody: Alexa fluor 488 goat anti-rabbit $\mathrm{IgG}$ (1:500, Invitrogen). Analysis was performed using FACSCalibur (Becton Dickinson, USA).

\section{Reverse-transcription PCR (RT-PCR)}

Total RNAs of cells were extracted using an RNeasy Plus mini kit (Quiagen, USA). DNA synthesis was performed for $60 \mathrm{~min}$ at $4^{\circ} \mathrm{C}$ and RTase inactivation was performed for $5 \mathrm{~min}$ at $95^{\circ} \mathrm{C}$ using Maxime RT Premix (iNtRON Biotechnology, Korea). PCR was performed using Maxime PCR Premix (iNtRON Biotechnology) supplemented with $18 \mu \mathrm{L} \mathrm{H}_{2} \mathrm{O}, 2 \mu \mathrm{L}$ primers $(10 \mu \mathrm{M})$ and sample $2 \mu \mathrm{L}$. The conditions of RT-PCR were followed: predenaturation for $10 \mathrm{~min}$ at $95^{\circ} \mathrm{C}$, denaturation for $30 \mathrm{~min}$ at $94^{\circ} \mathrm{C}$, anealing for $30 \mathrm{~s}$ at $53.5^{\circ} \mathrm{C}, 57.1^{\circ} \mathrm{C}$ and $60^{\circ} \mathrm{C}$, extinction for $45 \mathrm{~s}$ at $72^{\circ} \mathrm{C}$ and final extension for $10 \mathrm{~min}$ at $72^{\circ} \mathrm{C}$ for 34 cycles using (Pro s6325, Eppendorf). These RTPCR products were loaded on $2 \%$ agarose gels. On the other hands, total RNAs of porcine embryos at the blastocyst stage were extracted using an Absolutely RNA nanoprep kit (Stratagene, USA). DNA synthesis was performed for $60 \mathrm{~min}$ at $45^{\circ} \mathrm{C}$ and RTase inactivation was performed for $5 \mathrm{~min}$ at $95^{\circ} \mathrm{C}$ using a Revoscript RT Premix (iNtRON Biotechnology). PCR was performed using Maxime PCR Premix supplemented with $18 \mu \mathrm{L} \mathrm{H} \mathrm{H}_{2} \mathrm{O}, 2 \mu \mathrm{L}$ primers $(10 \mu \mathrm{M})$ and sample $2 \mu \mathrm{L}$. The conditions of RTPCR were followed: predenaturation for $10 \mathrm{~min}$ at $95^{\circ} \mathrm{C}$, denaturation for $30 \mathrm{~min}$ at $94^{\circ} \mathrm{C}$, anealing for $30 \mathrm{~s}$ at $53.3^{\circ} \mathrm{C}$, $57.6^{\circ} \mathrm{C}$ and $64^{\circ} \mathrm{C}$, extinction for $45 \mathrm{~s}$ at $72^{\circ} \mathrm{C}$ and final extension for $10 \mathrm{~min}$ at $72^{\circ} \mathrm{C}$ for 34 cycles using (Pro s6325,
Eppendorf). These PCR products were loaded on $2 \%$ agarose gels. Sequence of primers was listed in Table 1.

\section{Western blotting}

Cells treated with SOE were lysed in PRO-PREP ${ }^{\mathrm{TM}}$ Solution (iNtRON Biotechnology) for $20 \mathrm{~min}$ at $-20^{\circ} \mathrm{C}$. Proteins extracted from cells were separated on $12 \%$ SDSPAGE gels. Proteins were transferred onto a PVDF membrane using Mimi-PROTEAN Tetra Cell (BIO-RAD, USA). After being treated in the blocking solution (TBS containing $0.1 \%$ Tween-20, 5\% non-fat dry milk) for $1 \mathrm{~h}$ at room temperature, membrane was placed in the primary antibody solution: H3K9ac (1:500, Milipore), H3K9me3 (1:1,000, Abcam) or Histone 3 (H3, 1:5,000, Abcam) for overnight at $4^{\circ} \mathrm{C}$. Membrane was rinsed three times for 5 min each with PBS-T (PBS containing 0.1\% Tween-20) and incubated in the secondary antibody: Peroxidase conjugated goat anti rabbit $(1: 5,000$, KPL, USA) for $1 \mathrm{~h}$ at room temperature. WEST-one (InTRON Biotechnology) was used to detect chemiluminescence.

\section{Somatic cell nuclear transfer (SCNT)}

After incubation of CHXM for $16 \mathrm{~h}$, porcine COCs were in vitro matured for further 17 to $18 \mathrm{~h}$. Oocytes were exposed to TL-HEPES buffer containing $0.1 \%$ hyaluronidase and then vortexed for 4 to $5 \mathrm{~min}$ in order to remove cumulus cells. The denuded oocytes were dyed for $10 \mathrm{~min}$ in TCM-199 containing $25 \mathrm{mM}$ HEPES and 1 $\mu \mathrm{g} / \mathrm{mL}$ Hoechst 33342 and were then removed the spindle of the first meiotic anaphase/telophase I (AI/TI) in TCM199 containing $25 \mathrm{mM}$ HEPES and $5 \mu \mathrm{g} / \mathrm{mL}$ cytochalsin B (CB) (Lee and Campbell, 2006). To confirm the enucleation of oocyte, the aspirated karyoplast in the pipette was visualized under fluorescent light. Enucleated oocytes were cultured in TCM-199 supplemented with $10 \mathrm{ng} / \mathrm{mL}$ EGF, $0.5 \mu \mathrm{g} / \mathrm{mL} \mathrm{FSH}$ and $0.5 \mu \mathrm{g} / \mathrm{mL} \mathrm{LH}$ and $5 \mathrm{mM}$ Caffeine for $12 \mathrm{~h}$. After donor cells were transferred into the enucleated oocytes, the reconstructed oocytes were exposed to electric pulse of $1.25 \mathrm{KV} / \mathrm{cm}$ for $30 \mu$ s in $0.3 \mathrm{M}$ mannitol plus 0.1 $\mathrm{mM} \mathrm{MgSO}_{4}, 0.5 \mathrm{mM} \mathrm{CaCl}, 3 \mathrm{mg} / \mathrm{mL}$ BSA using a multiporator (Eppendorf, Germany). Fused oocytes were incubated with PZM5 medium at $39^{\circ} \mathrm{C}$ in an atmosphere of

Table 1. RT-PCR primers used for pluripotent marker genes

\begin{tabular}{|c|c|c|c|c|c|}
\hline Gene & Sequence of primer $\left(5^{\prime}-3^{\prime}\right)$ & $\mathrm{bp}$ & $\operatorname{Tm}\left({ }^{\circ} \mathrm{C}\right)$ cell & $\mathrm{Tm}\left({ }^{\circ} \mathrm{C}\right)$ embryo & References \\
\hline \multirow[t]{2}{*}{$\mathrm{SOX} 2$} & F-GCCTGGGCGCCGAGAGGA & 443 & 64 & 64 & NM003106 \\
\hline & R-GGCGAGCCGTTCATGTAGGTCTG & & & & \\
\hline \multirow[t]{2}{*}{ NANOG } & F-ATCCAGCTTGTCCCCAAAG & 438 & 60 & 57.6 & DQ447201 \\
\hline & R-ATTTCATTCGCTGGTTCTGG & & & & \\
\hline \multirow[t]{2}{*}{ OCT4 } & F-AGGTGTTCAGCCAAACGACC & 335 & 60 & 53.3 & NM00111306 \\
\hline & R-TGATCGTTTGCCCTTCTGGC & & & & \\
\hline \multirow[t]{2}{*}{ GAPDH } & F-GGGCATGAACCATGAGAAGT & 230 & 60 & 57.6 & AF017079 \\
\hline & R-AAGCAGGGATGATGTTCTGG & & & & \\
\hline
\end{tabular}


$5 \% \mathrm{CO}_{2}$ and $5 \% \mathrm{O}_{2}$. On day 2, cleaved embryos were transferred into fresh PZM5 medium until the blastocyst stage.

\section{Apoptotic assay of SCNT embryos}

Apoptotic assay of SCNT embryos at the blastocyst stage was performed using In Situ Cell Death Detection Kit (Hoffmann-La Roche Ltd, Switzerland). On Day 7, porcine SCNT embryos were fixed with $4 \%$ paraformaldehyde solution for $1 \mathrm{~h}$ at $4{ }^{\circ} \mathrm{C}$ and then rinsed three times with PBS. Samples were treated in the permeabilization buffer $(0.1 \%$ Triton X-100, 0.1\% sodium citrate in PBS) for $2 \mathrm{~min}$ on ice. These embryos were washed three times in PBS and then incubated in TUNEL reaction mixture for $60 \mathrm{~min}$ at $37^{\circ} \mathrm{C}$ without the light. After the TUNEL staining, embryos were washed three times and then stained with Hoechst 33342 $\left(50 \mathrm{pg} / \mathrm{mL}\right.$ ) for $10 \mathrm{~min}$ at $39^{\circ} \mathrm{C}$. Embryos were mounted with VECTASHIELD (Vector Laboratories, Inc). Images were captured a fluorescence microscope (LEICA DM 2500).

\section{Statistical analysis}

Data were analyzed by GenStat One-way ANOVA. A probability of $\mathrm{p}<0.05$ was considered to be statistically significant.

\section{RESULTS}

Effects of digitonin treatment on membrane permeabilization and viability of PFFs

The plasma membrane of porcine fetal fibroblast cells (PFFs) should be permeable to allow transport of unique oocyte factors existed in Siberian sturgeon oocyte extracts (SOE) into the nucleus or cytoplasm of cell. Digitonin, cholesterol-binding family of bacterial exotoxin, is one of the most frequently used agents for causing transient pores in the plasma membrane of cell, which is sufficient for the passive diffusion of proteins up to the size of $100 \mathrm{kDa}$ (Adam et al., 1992; Walev et al., 2001; Geelen, 2005). However, the reactivity of digitonin depends on cell types and species (Miyamoto et al., 2008). Therefore, in the preliminary experiment, determining the optimal concentration of digitonin to PFFs was examined. As the result, the permeability of cells recovered after being exposed to 4 and $6 \mu \mathrm{g} / \mathrm{mL}$ of digitonin for $2 \mathrm{~min}$ were significantly elevated more than $90 \%$ (Figure $1 \mathrm{~A})(\mathrm{p}<0.05)$. However, the viability of cells treated with $4 \mu \mathrm{g} / \mathrm{mL}$ of digitonin showed significantly higher than those in $6 \mu \mathrm{g} / \mathrm{mL}$ of digitonin (Figure 1B) $(\mathrm{p}<0.05)$. Considering permeability and viability of the cells after being treated with digitonin, 4 $\mu \mathrm{g} / \mathrm{mL}$ of digitonin was determined to the optimal concentration to PFFs.

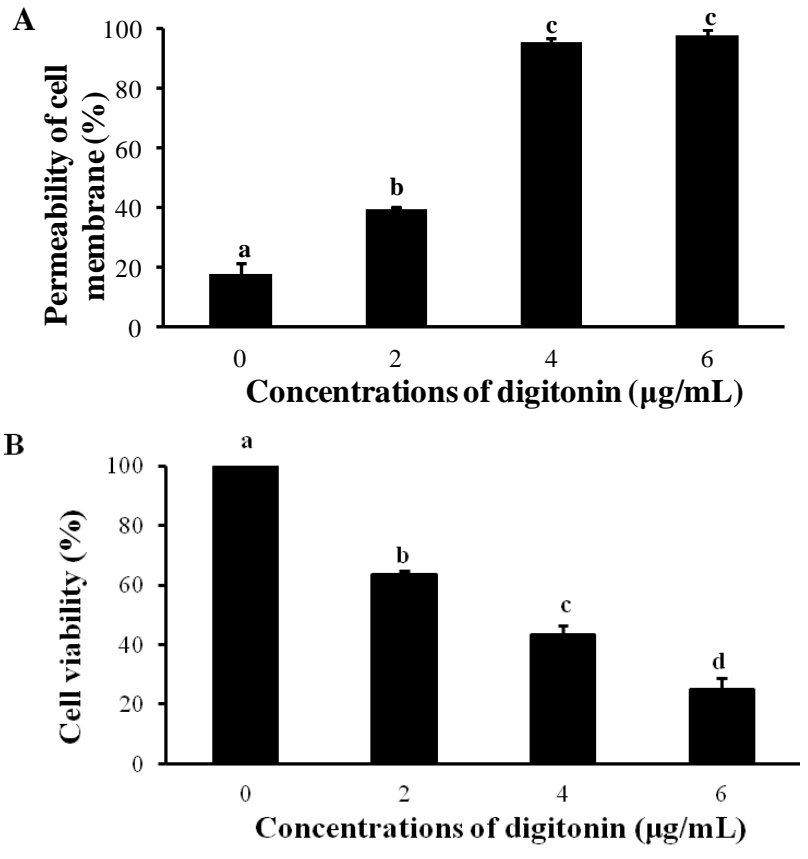

Figure 1. Determinations of the optimal concentration of digitonin on cell membrane permeability (A) and cell viability (B). Permeabilization and cell viability of PFFs treated with $0,2,4$ or 6 $\mu \mathrm{g} / \mathrm{mL}$ of digitonin for $2 \mathrm{~min}$ on ice were assessed by the staining of $0.8 \mathrm{mM}$ trypan blue solution. (A) The trypan blue staining shows permeability of cell membrane. (B) The cell viability was calculated as the number of survived cells subtracted from the total cell number. Different letters on bars represent a significant difference $(p<0.05)$. The results of three replicates were presented.

Bars represent mean \pm SEM.

\section{Determination of the optimal period of exposure to SOE}

In order to determine the optimal period of exposure to SOE, the permeabilized cells pretreated with $4 \mu \mathrm{g} / \mathrm{mL}$ of digitonin were incubated in the extracts for $0,1,3,5$ or $7 \mathrm{~h}$, respectively. The histone acetylation status of the SOEtreated cells was assessed using an antibody specific to the acetylated form of $\mathrm{H} 3 \mathrm{~K} 9$. As shown in Figure 2, the intensity of $\mathrm{H} 3 \mathrm{~K} 9 \mathrm{ac}$ staining in the PFFs was increased after incubation of $5 \mathrm{~h}$ with the SOE. The intensity of H3K9ac staining in the cells was significantly elevated after treatment of SOE for $7 \mathrm{~h}(\mathrm{p}<0.05)$. In the experiment, $7 \mathrm{~h}$ was chosen for the optimal period of exposure to SOE. The morphology of the pre-treating PFFs after being exposed to SOE for $7 \mathrm{~h}$ was also examined. The nuclei of the permeabilized cells treated with SOE were observed more swelled than those of non-treated cells (not shown).

\section{Changes in DNA methylation and histone acetylation of PFFs exposed to SOE}

Not only chromatin of undifferentiated cells retains more epigenetic marks associated with transcriptionally active genes, but also less epigenetic marks which are 
A
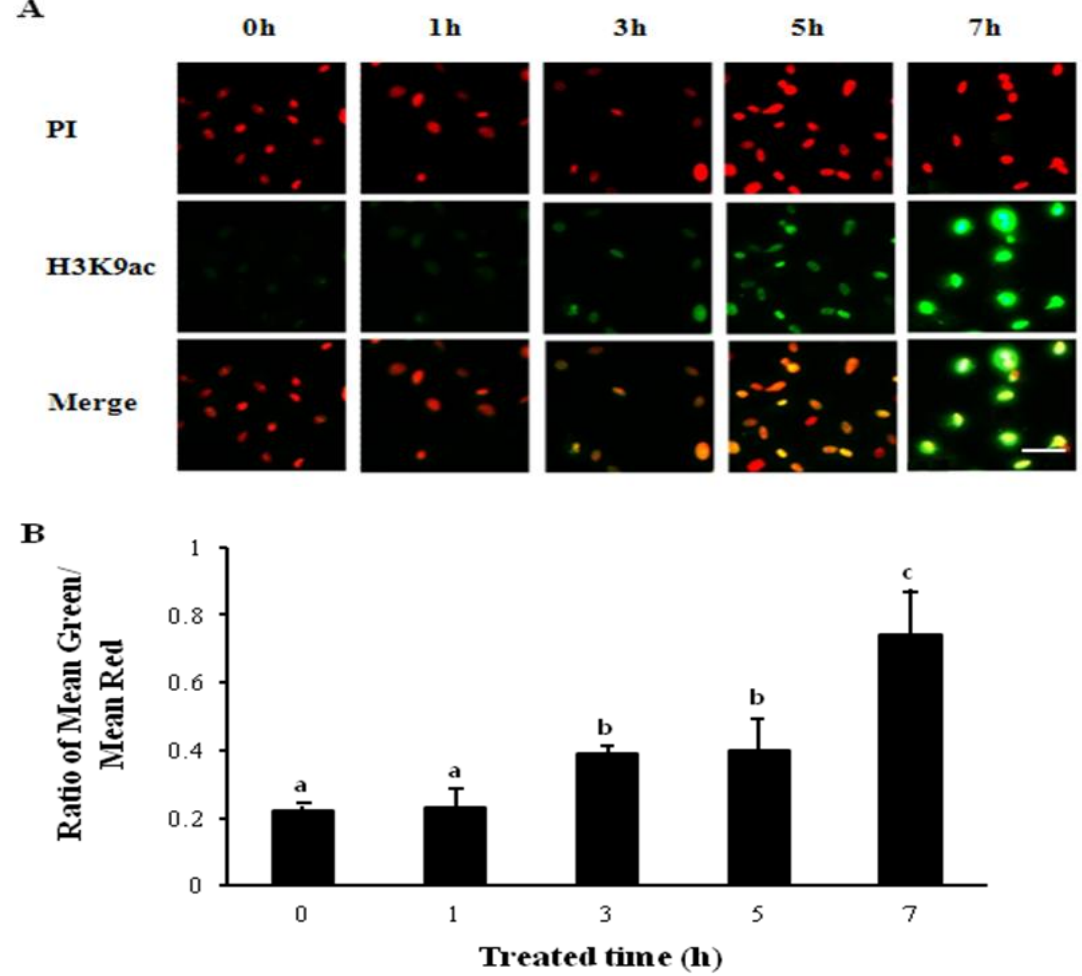

Figure 2. Determination of the optimal period of exposure to Siberian sturgeon oocyte extract treated cells using immunostaining. The level of histone acetylation was detected using Alexaflour 488-labelled antibodies bound to antibodies specific to H3K9ac. (A) Examples of images obtained when visualizing H3K9ac of PFFs immunostained after treatment of SOE for 0, 1, 3, 5, or $7 \mathrm{~h}$. Green: Alexaflour 488-labeled H3K9ac, red: PI stained nuclei. (B) The histone acetylation status was calculated as the intensity of Alexaflour 488-labeling divided by the intensity of nuclear labeling with PI. Different letters on bars represent a significant difference $(\mathrm{p}<0.05)$. The results of three replicates were presented. Bars represent mean \pm SEM. Scale bar $=50 \mu \mathrm{m}$.

associated with transcriptionally repressed genes (Meshorer et al., 2006). Therefore, we assessed the levels of active mark $(\mathrm{H} 3 \mathrm{~K} 9 \mathrm{ac})$ and repressive mark $(\mathrm{H} 3 \mathrm{~K} 9 \mathrm{me} 3)$ in the PFFs after treatment with SOE. The intensity of H3K9ac staining in the PFFs was significantly increased after treatment with SOE for $7 \mathrm{~h}$ (Figure $3 \mathrm{~A}$ and $\mathrm{B})(\mathrm{p}<0.05)$. In contrast to the intensity of $\mathrm{H} 3 \mathrm{~K} 9 \mathrm{ac}$, the intensity of $\mathrm{H} 3 \mathrm{~K} 9 \mathrm{me} 3$ staining in the cells was significantly decreased after the treatment of SOE (Figure 4A and B) $(\mathrm{p}<0.05)$. We also proved these observations using FACS analysis and western blotting method. The intensity of $\mathrm{H} 3 \mathrm{~K} 9 \mathrm{ac}$ staining in the PFFs exposed to SOE was increased (Figure 3C and 5), whereas the intensity of $\mathrm{H} 3 \mathrm{~K} 9 \mathrm{me} 3$ in the cells after treatment with SOE was decreased (Figure 4C and 5). Thus, these results indicated that some of oocyte factors existed in SOE has the ability to remodel chromatin of porcine somatic cells.

Reactivation of pluripotency genes in PFFs after treatment of SOE

Reactivation of pluripotency genes in the cells following the treatment of SOE was examined. As shown in Figure 6, the SOE-treated cells were slightly induced expressions of pluripotent markers (Oct4, Nanog and Sox2).
However, non-treated permeabilized cells did not express any pluripotency marker genes, whereas the pluripotency genes were highly expressed in porcine induced pluripotent stem cells (iPSCs) (Figure 6).

\section{Effects of SOE on histone acetylation in SCNT embryos at the zygote stage}

In order to examine the change in chromatin of SCNT embryos reconstructed by pre-treating PFFs with SOE to be used as nuclear donors prior to SCNT, the intensity of H3K9ac staining in porcine SCNT embryos was measured. In vitro fertilized (IVF), SCNT and SCNT zygotes reconstructed by using SOE-treated cells were examined using an antibody to $\mathrm{H} 3 \mathrm{~K} 9 \mathrm{ac}$. Interestingly, the intensity of histone acetylation in the zygote stage SCNT embryos reconstructed using by SOE-treated cells was similar to that of IVF embryos (Figure 7). However, the intensity of histone acetylation (H3K9ac) staining in porcine cloned embryos reconstructed using by SOE-treated cells was significantly increased as compared to that of SCNT embryos $(\mathrm{p}<0.05)$ (Figure 7).

Development of SCNT embryos reconstructed by pretreating PFFs with SOE to be used as nuclear donors 
A

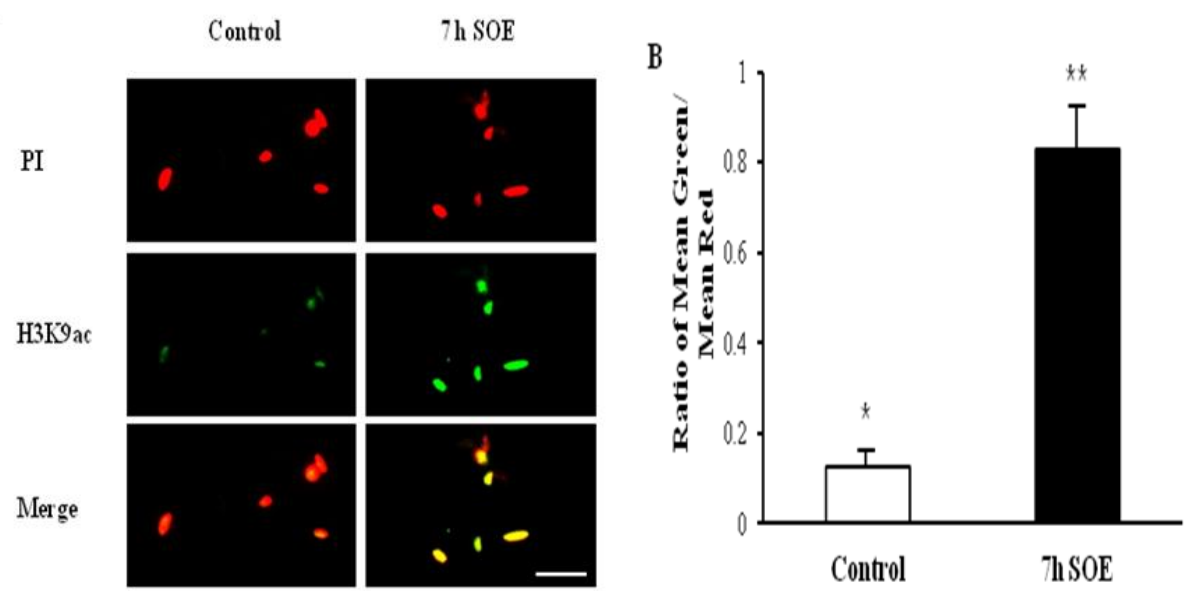

C

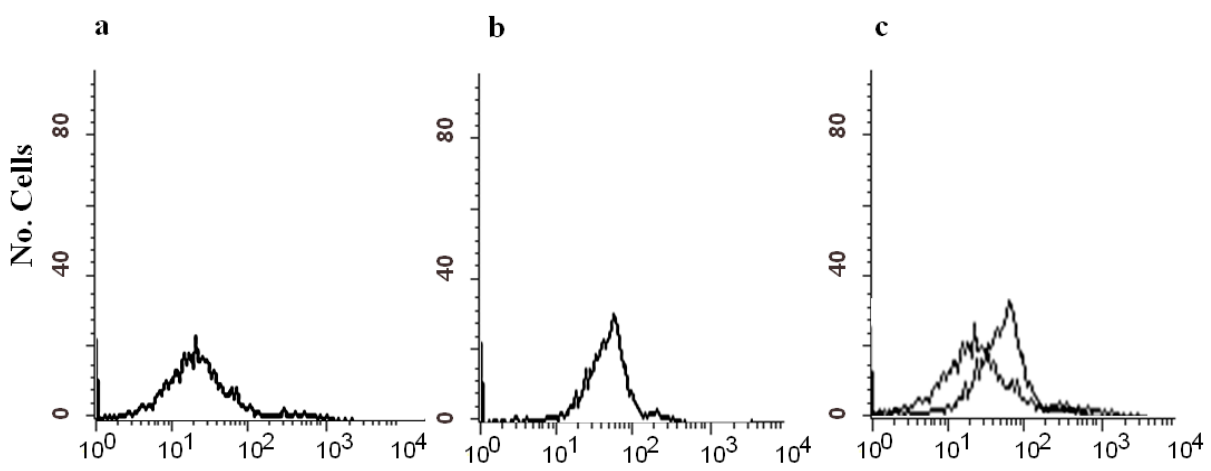

Fluorescent intensity of H3K9ac

Figure 3. The histone acetylation status of $\mathrm{H} 3 \mathrm{~K} 9 \mathrm{ac}$ in the control and SOE-treated cells using immunostaining. (A) Examples of images obtained when visualizing H3K9ac of PFFs immunostained in the control and SOE-treated cells for 7 h. Green: Alexaflour 488-labeled H3K9ac, Red: PI stained nuclei. (B) The histone acetylation status was calculated as the intensity of Alexaflour 488-labeling divided by the intensity of nuclear labeling with PI. (C) FACS sorting shows the intensity of fluorescence in the control (a), SOE-treated cells (b), and merge (c). The results of three replicates were presented. $* * *$ Values with different superscripts on bars are significant difference $(\mathrm{p}<0.05)$. Bars represent mean \pm SEM. Scale bar $=50 \mu \mathrm{m}$.

\section{prior to SCNT}

Based on the result, the in vitro developmental competence of porcine SCNT embryos reconstructed by using SOE-treated cells was examined. No difference was observed in the number of fused couplets that cleaved between the control and SOE-treated group (Table 2). However, there was a significant increase in the percentage of fused couplets that developed to the blastocyst stage in SOE-treated group (Table 2). The developmental competence of SOE-treated SCNT embryos to the blastocyst stage was significantly higher than that of the control $(21.0 \%$ vs $13.8 \%)(\mathrm{p}<0.05)$.

Cell viability in SCNT embryos at the blastocyst stage reconstructed by using SOE-treated cells

The number of cells in porcine SCNT embryos at the blastocyst stage by pre-treating PFFs with SOE to be used as nuclear donors was examined (Table 3). The overall number of porcine cloned embryos in SOE-treated group was significantly increased as compared to that of the control $(23.5 \pm 2.5$ vs $15.5 \pm 4.3)(\mathrm{p}<0.05)$. In addition, the number of apoptotic cells in the SOE-treated cloned embryos was slightly decreased as compared to that in control cloned embryos $(5.5 \pm 3.1$ vs $8.0 \pm 2.8)$. There was a significant difference in the percentage of apoptotic cells between the control and SOE-treated group $(51.6 \%$ vs $24.4 \%)(\mathrm{p}<0.05)$.

\section{Pluripotent gene expressions of SOE-treated cloned embryos at the blastocyst stage}

We investigated that whether treatment of the permeabilized cells with the extracts prepared from SOE prior to their use as nuclear donors for SCNT affects expression of the pluripotent genes (Oct4, Nanog and Sox2) in porcine SCNT embryos at the blastocyst stage. As shown in Figure 8, the levels of pluripotent related genes expression 
A
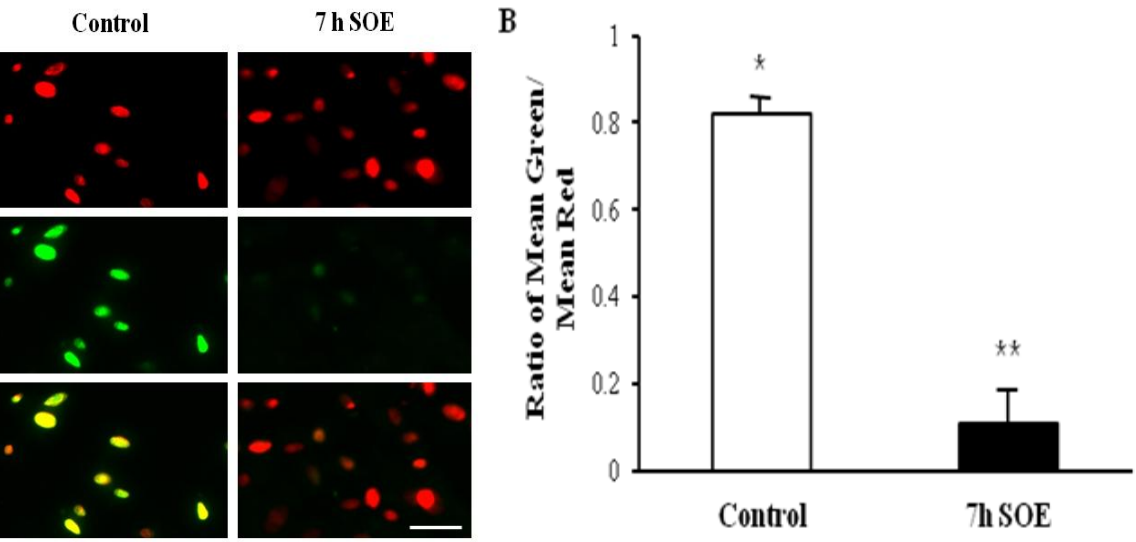

C
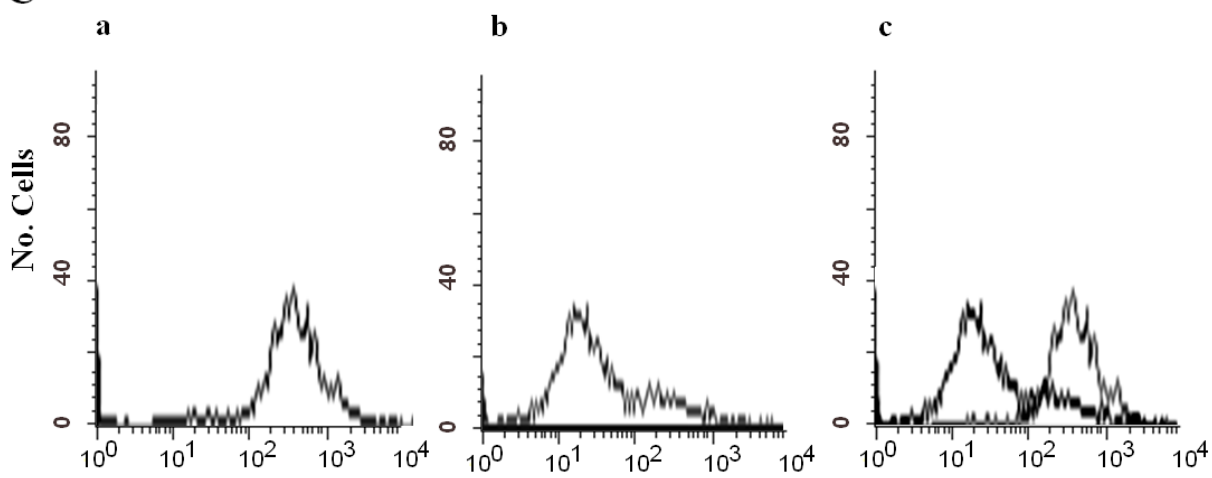

Fluorescent intensity of $\mathrm{H} 3 \mathrm{~K} 9 \mathrm{me} 3$

Figure 4. The DNA methylation status of $\mathrm{H} 3 \mathrm{~K} 9 \mathrm{me} 3$ in the control and SOE-treated cells using immunostaining. (A) Examples of images obtained when visualizing H3K9me3 of PFFs immunostained in the control and SOE-treated cells for 7 h. Green: Alexaflour 488-labeled H3K9me3, Red: PI stained nuclei. (B) The DNA methylation status was calculated as the intensity of Alexaflour 488-labeling divided by the intensity of nuclear labeling with PI. (C) FACS sorting shows the intensity of fluorescence in the control (a), SOE-treated cells (b), and merge (c). The results of three replicates are presented. $* * *$ Values with different superscripts on bars are significant difference $(\mathrm{p}<0.05)$. Bars represent mean \pm SEM. Scale bar $=50 \mu \mathrm{m}$.

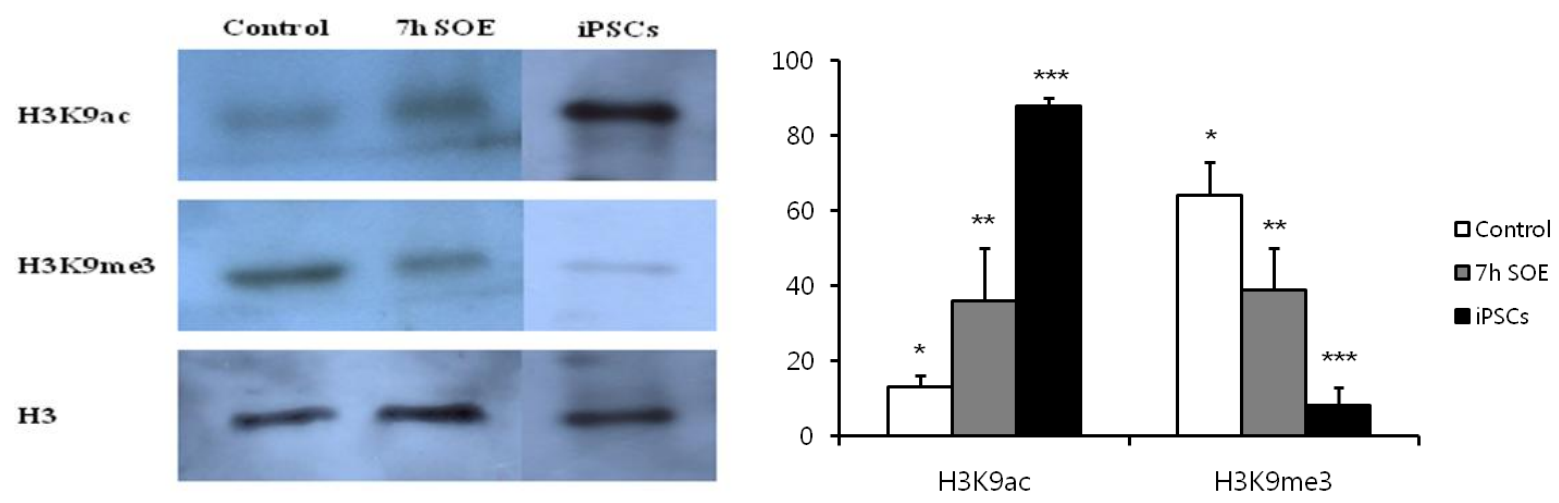

Figure 5. H3K9ac and H3K9me3 in cells incubated in Siberian sturgeon oocyte extract. Reversible permeabilized PFFs were incubated for $7 \mathrm{~h}$ in SOE and stained for antibodies. Immunoblot of H3K9ac, H3K9me3 and H3 in the control, SOE-treated cells and porcine induced pluripotent stem cells (iPSCs). 

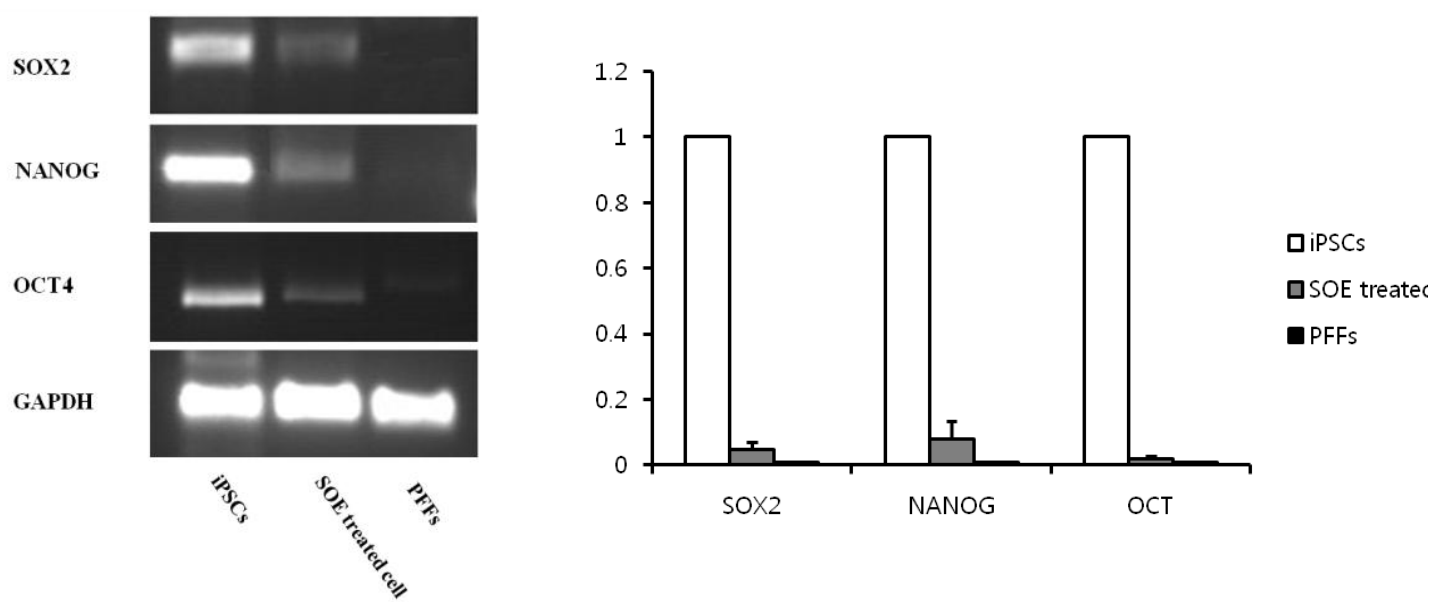

Figure 6. Inductions of pluripotent marker genes in PFFs after incubation with SOE. RT-PCR analysis showed that Sox2, Nanog, and Oct4 genes were slightly expressed in SOE-treated cells, which was not expressed in the control cells. Glyceraldehydes-3-phosphate dehydrogenase (GAPDH) was used as the standard gene.

A
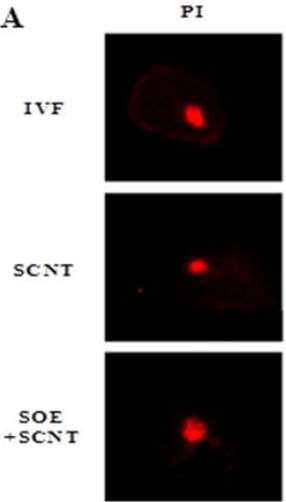
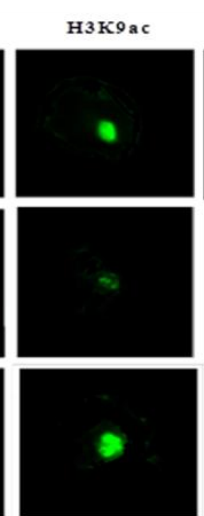
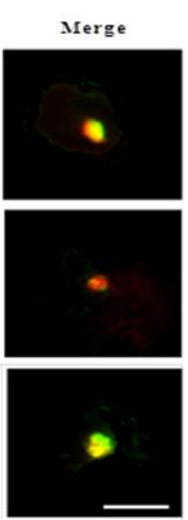

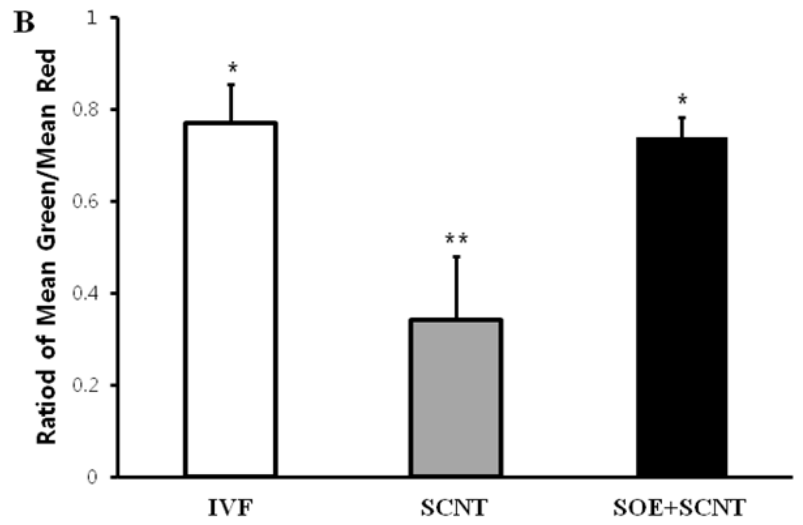

Figure 7. The intensities of H3K9ac of IVF, SCNT, and SCNT embryos at the zygote stage reconstructed by using SOE-treated cells. (A) Examples of images obtained when visualizing H3K9ac of PFFs immunostained in IVF, SCNT, and SCNT embryos reconstructed by SOE-treated donor cells. Green: Alexaflour 488-labeled H3K9ac, Red: PI stained nuclei. (B) The histone acetylation status was calculated as the intensity of Alexaflour 488-labeling divided by the intensity of nuclear labeling with PI. The results of three replicates are presented. $* * *$ Values with different superscripts on bars are significant difference $(\mathrm{p}<0.05)$. Bars represent mean \pm SEM. Scale bar $=$ $50 \mu \mathrm{m}$.
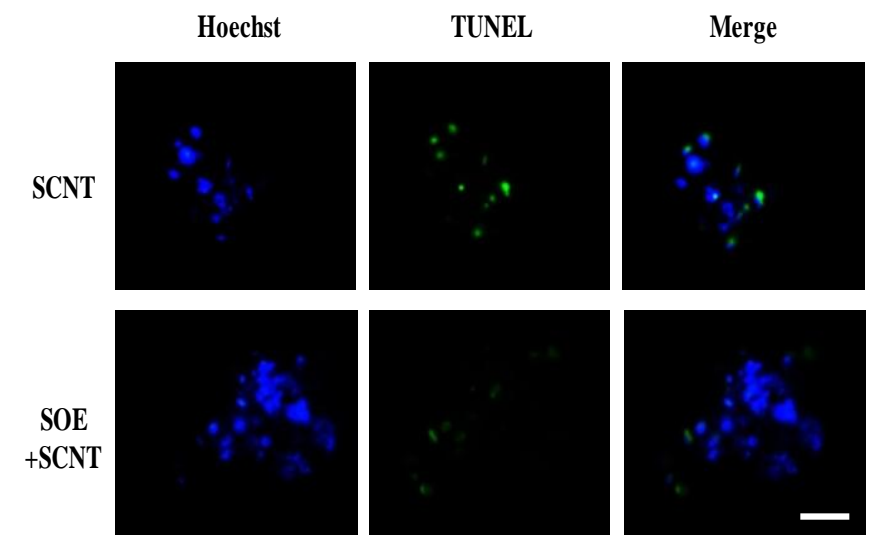

Figure 8. TUNEL assay of porcine SCNT embryos at the blastocyst stage reconstructed by using SOE-treated cells. Apoptotic assay of porcine SCNT embryo was performed using In Situ Cell Death Detection Kit. On day 7, SCNT embryos were fixed, permeabilised and then incubated in TUNEL reation mixture for $1 \mathrm{~h}$. Blue: Hoechst 33342, Green: TUNEL. The number of apoptotic cells in SCNT embryos reconstructed by using SOE-treated cells was significantly decreased as compared to normal SCNT embryos. Scale bar $=50$ $\mu \mathrm{m}$. 


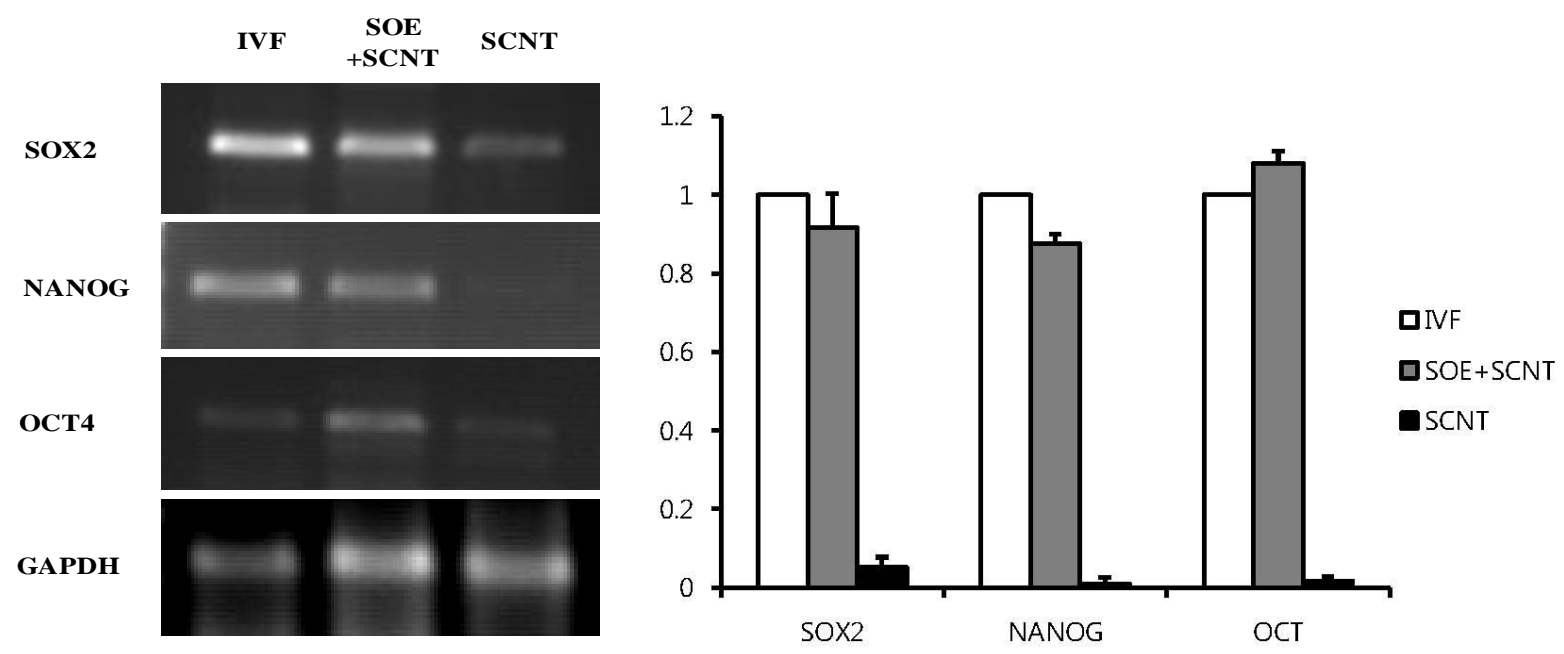

Figure 9. Expression of pluripotent marker genes in porcine SCNT embryos at the blastocyst stage reconstructed by using SOE-treated cells. RT-PCR analysis showed that Sox2, Nanog, and Oct4 genes in porcine SCNT embryos at the blastocyst stage reconstructed by using SOE-treated cells as donor cells were expressed similar to those in IVF embryos, which was not expressed in normal SCNT embryos. Glyceraldehydes-3-phosphate dehydrogenase (GAPDH) was used as the standard gene.

in porcine cloned embryos reconstructed by using the SOEtreated cells were quite similar to those in IVF embryos as the control. However, Sox2, Nanog and Oct4 in the cloned embryos were significantly less expressed when compared to those in IVF and SOE-treated cloned embryos $(\mathrm{p}<0.05)$ (Figure 9).

\section{DISCUSSION}

Unique oocyte factors necessary for the successful reprogramming of differentiated cells have been explored since the report of Dolly the sheep (Wilmut et al., 1997). It is generally accepted that even though successful production of cloned offspring following somatic cell nuclear transfer (SCNT) occurs across a range of species, so far, the efficiency of development to term and survival remains low. Faulty development caused by SCNT has been attributed to incomplete or aberrant reprogramming of the transferred nuclei into the recipient environment (Rideout et al., 2001). A number of strategies to resolve the insufficient or incomplete epigenetic reprogramming occurred by SCNT have been continuously reported (Martin et al., 2006). In the present study, we focused on epigenetic modifications associated with reprogramming of somatic cells in extracts

Table 2. Developmental competence of porcine SCNT embryos reconstructed by using SOE-treated cells

\begin{tabular}{lcccc}
\hline Group & $\begin{array}{c}\text { No. } \\
\text { Oocytes }\end{array}$ & $\begin{array}{c}\text { No. } \\
\text { Fused (\%) }\end{array}$ & $\begin{array}{c}\text { No. } \\
\text { Cleaved (\%) }\end{array}$ & $\begin{array}{c}\text { No. } \\
\text { Blastocysts } \\
(\%)\end{array}$ \\
\hline Control & 245 & $239(97.6)$ & $191(79.9)$ & $33(13.8)^{\mathrm{a}}$ \\
SOE-treated & 313 & $290(92.7)$ & $248(85.5)$ & $61(21.0)^{\mathrm{b}}$ \\
\hline $\begin{array}{l}\text { a,b Values in same columns with different superscripts are significantly } \\
\text { different }(\mathrm{p}<0.05) .\end{array}$
\end{tabular}

of interspecies oocytes prior to the use of donor cells introduced into the recipient oocyte.

According to previous studies, pre-treatment with Xenopus laevis oocyte extracts at the GV stage could convert reprogramming of differentiated cells into undifferentiated or pluripotent state (Hansis et al., 2004; Alberio et al., 2005). It was importantly considered to be permeabilized the somatic cells because the treatment of extracts without this procedure may results in little reprogramming efficiency (Miyamoto et al., 2008). Generally the subsequent reprogramming of somatic cells with oocyte extracts may depend on the permeability of cell types as well as the activity of extracts. The permeabilization of plasma membrane is required for nuclear transport of egg-derived factors. Streptolysin O (SLO) is one of the most frequently used agents to be permeabilized on the plasma membrane of cell. However, it was reported that SLO has the harmful effect on cell survival. In the preliminary experiment, $4 \mu \mathrm{g} / \mathrm{mL}$ of digitonin was able to be reversibly permeabilized on the plasma membrane of porcine fetal fibroblast cells (PFFs) with approximately $40 \%$ survival rates.

By the aid of the permeabilization, the treatment of Siberian sturgeon oocyte extracts (SOE) could induce

Table 3. Cells viability of porcine SCNT embryos at the blastocyst stage produced from SOE-treated donor cells

\begin{tabular}{lccc}
\hline Group & $\begin{array}{c}\text { No. Cells } \\
\text { of blastocysts }\end{array}$ & $\begin{array}{c}\text { No. Apoptotic } \\
\text { cells } \\
\text { of blastocysts }\end{array}$ & $\begin{array}{c}\text { Rate } \\
\text { of apoptosis } \\
(\%)\end{array}$ \\
\hline Control & $15.5 \pm 4.3^{\mathrm{a}}$ & $8.0 \pm 2.8$ & $51.6^{\mathrm{a}}$ \\
SOE-treated & $23.5 \pm 2.5^{\mathrm{b}}$ & $5.5 \pm 3.1$ & $24.4^{\mathrm{b}}$ \\
\hline
\end{tabular}

$\overline{\mathrm{a}, \mathrm{b}}$ Values in same columns with different superscripts are significantly different $(\mathrm{p}<0.05)$. 
epigenetic modifications of somatic cells ex-ovo. Our result has shown that the changes in both Histone H3 Lys-9 acetylation (H3K9ac: mark associated with active chromatin) and Histone H3 Lys-9 methylation (H3K9me3: mark associated with transcriptional repression) were induced by using the SOE for a brief time of incubation (7 h), which are associated with controlling heterochromatin organization. Following treatment with the SOE, the intensity of $\mathrm{H} 3 \mathrm{~K} 9 \mathrm{me} 3$ staining was significantly decreased whereas the intensity of $\mathrm{H} 3 \mathrm{~K} 9 \mathrm{ac}$ in both the PFFs and porcine SCNT embryos at the zygote stage was significantly increased. Interestingly, the changes in both $\mathrm{H} 3 \mathrm{~K} 9 \mathrm{ac}$ and H3K9me3 staining after the SOE treatment showed similarity to those of epigenetic modifications induced by using amphibian oocyte extract (Bian et al., 2009; Rathbone et al., 2010). Further to the previous experiments, the level of $\mathrm{H} 3 \mathrm{~K} 9 \mathrm{ac}$ in the PFFs treated with SOE was also significantly increased but the level of H3K9me3 was slightly decreased as observed in porcine induced pluripotent stem cells (iPSCs) using western blotting. These findings indicated that exposure to SOE for a brief period alters some epigenetic modifications (DNA demethylation and histone acetylation) of porcine somatic cells. This event is reminiscent of the atypical bivalent epigenetic signature of ES cells (Bernstein et al., 2006), which could promote reprogramming by resetting the memory of the somatic nuclei.

Among the pluripotent markers, Oct4 is well known as retaining demethylated state during cell division and fulfilling an auto-regulatory capacity (Maherali et al., 2008; Bian et al., 2009). We investigated that the expressions of pluripotency related genes (Nanog, Oct4, and Sox2) were slightly reactivated in porcine somatic cells after being treated with SOE in a brief time $(7 \mathrm{~h})$. On the other hand, Nanog was generally expressed during the incubation of amphibian oocyte extracts, however, Oct4 was shown to express after several days of the culture (Bian et al., 2009). In the study, Oct4 and Nanog were expressed following a brief period of exposure to SOE.

By the way, Oct4 and Sox 2 are essential for maintaining pluripotency of ES cells (Niwa, 2007) and for establishing iPS cells (Takahashi et al., 2007). These genes were also reactivated in SOE-treated cells, exactly similar to be permeabilized with digitonin and then cultured with amphibian oocyte extracts in vitro (Miyamoto et al., 2007). These results suggest that the reversibly permeabilization system with digitonin can be used for the reactivation of pluripotent genes in somatic cell after co-culture with cellular or oocyte extracts. The expression of Nanog is reactivated by Oct4 and Sox2 (Niwa, 2007) and enhances reprogramming efficiency of somatic cells after cell fusion (Silva et al., 2006). Therefore, the expression of these pluripotent related genes may convert somatic cells to partially dedifferentiated state after treatment with extracts.

The cytoplasmic environment of the fully matured oocyte is an important factor influencing reprogramming capability of donor cells used for SCNT in mammals. As one of attempts to enhance the efficiency of SCNT, the somatic nuclei used as donor cells may be needed to reprogram preferentially by using cellular or oocyte extracts. In this experiment, in vitro developmental competence of porcine cloned embryos reconstructed by using pre-treating PFFs with the SOE to be used as nuclear donor prior to SCNT was examined. The in vitro development to the blastocyst stage in SCNT embryos reconstructed by using the SOE-treated cells was significantly higher when compared to that of the non-treated SCNT embryos. Based on the result of TUNEL, the total cell number of cloned embryos at the blastocyst stage in SOE-treated group was significantly increased as compared to that of SCNT embryos. In addition, the pluripotent related genes expressions in porcine cloned embryos reconstructed by using the SOE-treated cells were shown similar to those in IVF embryos. These results demonstrated that a combination of SCNT technique with the ex-ovo methods can improve the developmental competence and the quality of cloned embryos.

As a consequence of all experiments, the Siberian sturgeon oocyte extract (SOE) have an ability to convert porcine somatic cells into undifferentiated state following a brief period of incubation $(7 \mathrm{~h})$. Additionally, the in vitro development and quality of the blastocyst stage SCNT embryos were improved when produced by the use of SOEtreated cells as donor nucleus. The strategy of epigenetic remodeling by the treatment of SOE may contribute a useful tool for reprogramming of somatic cell nuclei. We need to exploit the nuclear reprogramming of differentiated cells into undifferentiated state induced by using interspecies cell or oocyte extracts. Furthermore, studies to select extract-treated cells for SCNT are required for optimized exploitation of the reprogramming ability of the extract.

\section{ACKNOWLEDGEMENTS}

This work was partly supported by the National Research Foundation of Korea funded by the Korean Government (NRF-2011-0013703) and Cooperative Research Program for Agriculture Science \& Technology Development (Project No. PJ009418022013 and PJ009117022013), Rural Development Administration, Republic of Korea.

\section{REFERENCES}

Adam, S. A., R. Sterne-Marr, and L. Gerace. 1992. Nuclear protein 
import using digitonin-permeabilized cells. Methods Enzymol. 219:97-110.

Alberio, R., A. Johnson, R. Stick, and K. H. S. Campbell. 2005. Differential nuclear remodeling of mammalian somatic cells by Xenopus laevis oocyte and egg cytoplasm. Exp. Cell Res. 307:131-141.

Bernstein, B. E., T. S. Mikkelsen, X. Xie, M. Kamal, D. J. Huebert, J. Cuff, B. Fry, A. Meissner, M. Wernig, K. Plath, R. Jaenisch, A. Wagschal, R. Feil, S. L. Schreiber, and E. S. Lander. 2006. A bivalent chromatin structure marks key developmental genes in embryonic stem cells. Cell 125:315-326.

Bian, Y., R. Alberio, C. Allegrucci, K. H. S. Campbell, and A. Johnson. 2009. Epigenetic chromatin marks in somatic chromatin are remodeled to resemble pluripotent nuclei by amphibian oocyte extracts. Epigenetics 4:194-202.

Blau, H. M. and B. T. Blakely. 1999. Plasticity of cell fate: insights from heterokaryons. Semin. Cell. Dev. Biol. 10:267-272.

Campman, F. A. and J. P. Eenennaam. 2007. The egg polarization index or PI. University of FLORIDA IFAS extension 153:1-5.

Geelen, M. J. 2005. The use of digitonin-permeabilized mammalian cells for measuring enzyme activities in the course of studies on lipid metabolism. Anal. Biochem. 347:1-9.

Hansis, C., G. Barreto, N. Maltry, and C. Niehrs. 2004. Nuclear reprogramming of human somatic cells by Xenopus egg extract requires BRG1. Curr. Biol. 14:1475-1480.

Håkelien, A. M., H. B. Landsverk, J. M. Robl, B. S. Skålhegg, and P. Collas. 2002. Reprogramming fibroblasts to express T-cell functions using cell extract. Nat. Biotechnol .20:460-466.

Hochedilinger, K. and R. Jaenisch. 2002. Monoclonal mice generated by nuclear transfer from mature $\mathrm{B}$ and $\mathrm{T}$ donor cells. Nature 415:1035-1038.

Jouneau, A. and J. P. Renard. 2003. Reprogramming in nuclear transfer. Curr. Opin. Genet. Dev. 13:486-491.

Konrad, H. and J. Rudolf. 2006. Nuclear reprogramming and pluripotency. Nature 441:1061-1067.

Landsverk, H. B., A. M. Håkelien, T. Küntziger, J. M. Robl, B. S. Skålhegg, and P. Collas. 2002. Reprogrammed gene expression in a somatic cell-free extract. EMBO Rep. 3:384-389.

Lee, J. H. and K. H. S. Campbell. 2006. Effects of enucleation and caffeine on Maturation-Promoting Factor (MPF) and MitogenActivated Protein Kinase (MAPK) activities in ovine oocytes used as recipient cytoplasts for nuclear transfer. Biol. Reprod. 74:691-698

Maherali, N. and K. Hochedlinger. 2008. Guidelines and techniques for the generation of induced pluripotent stem cells. Cell Stem Cell 3:595-605.

Martin, C., N. Beaujean, V. Brochard, C. Audouard, D. Zink, and P. Debey. 2006. Genome restructuring in mouse embryos during reprogramming and early development. Dev. Biol. 292:317332.

Meshorer, E., D. Yellajoshula, E. George, P. J. Scambler, D. T. Brown, and T. Misteli. 2006. Hyperdynamic plasticity of chomatin proteins in pluripotent embryonic stem cells. Dev. Cell 10:105-116.

Miyamoto, K., T. Furusawa, M. Ohnuki, S. Goel, T. Tokunuga, N. Minami, M. Yamada, K. Ohsumi, and H. Imai. 2007. Reprogramming events of mammalian somatic cells induced by Xenopus laevis egg extracts. Mol. Reprod. Dev. 74:1268-
1277.

Miyamoto, K., T. Yamashita, T. Tsukiyama, N. Kitamura, N. Minami, M. Yamada, and H. Imai. 2008. Reversible membrane permeabilization of mammalian cells treated with digitonin and its use for inducing nuclear reprogramming by Xenopus egg extracts. Cloning Stem Cells 10:535-542.

Morgan, H. D., F. Santos, K. Green, W. Dean, and W. Reik. 2005. Epigenetic reprogramming in mammals. Hum. Mol. Genet. 14: R47-R58.

Niwa, H. 2007. How is pluripotency determined and maintained? Development 134:635-646.

Rathbone, A. J., P. A. Fisher, J. H. Lee, J. Craigon, and K. H. S. Campbell. 2010. Reprogramming of ovine somatic cells with Xenopus laevis oocyte extract prior to SCNT improves live birth rate. Cell. Reprogram. 12:609-616.

Rideout, W. M., K. Eggan, and R. Jaenisch. 2001. Nuclear cloning and epigenetic reprogramming of the genome. Science 293: 1093-1098.

Silva, J., I. Chambers, S. Pollard, and A. Smith. 2006. Nanog promotes transfer of pluripotency after cell fusion. Nature 441: 997-1001.

Tada, M., T. Tada, L. Lefebvre, S. C. Barton, and M. A. Surani. 1997. Embryonic germ cells induce epigenetic reprogramming of somatic nucleus in hybrid cells. EMBO J. 16:6510-6520.

Takahashi, K., K. Tanabe, M. Ohnuki, M. Narita, T. Ichisaka, K. Tomoda, and S. Yamanaka. 2007. Induction of pluripotent stem cells from adult human fibroblasts by defined factors. Cell 131:861-872.

Takahashi, K. and S. Yamanaka. 2006. Induction of pluripotent stem cells from mouse embryonic and adult fibroblast cultured by defined factor. Cell 126: 663-676.

Tang, S., Y. Wang, D. Zhang, Y. Gao, Y. Ma, B. Yin, J. Sun, J. Liu, and Y. Zhang. 2009. Reprogramming donor cells with oocyte extracts improves in vitro development of nuclear transfer embryos. Ani. Reprod. Sci. 115:1-9.

Taranger, C. K., A. Noer, A. L. Sorensen, A. M. Hakelien, A. C. Boquest, and P. Collas. 2005. Induction of dedifferentiation, genomewide transcriptional programming, and epigenetic reprogramming by extracts of carcinoma and embryonic stem cells. Mol. Biol. Cell 16:5719-5735.

Wakayama, T., A. C. F. Perry, M. Zuccotti, K. R. Johnson, and R. Yanagimachi. 1998. Full-term development of mice from enucleated oocytes injected with cumulus cell nuclei. Nature 394:369-373

Walev, I., S. C. Bhakdi, F. Hofmann, N. Djonder, A. Valeva, K. Aktories, and S. Bhakdi. 2001. Delivery of proteins into living cells by reversible membrane permeabilization with streptolysin-O. Proc. Natl. Acad. Sci. USA 98:3185-3190.

Wilmut, I., A. E. Schnieke, J. McWhir, A. J. Kindm, and K. H. S. Campbell. 1997. Viable offspring derived from fetal and adult mammalian cells. Nature 385:810-813

Ye, J., A. P. F. Flint, K. H. S. Campbell, and M. R. Luck. 2002. Synchronization of porcine oocyte meiosis using cycloheximide and its application to the study of regulation by cumulus cells. Reprod. Fertil. Dev. 14:433-442. 